\title{
ANALISIS CUSTOMER SATISFACTION DAN BEHAVIORAL INTENTION DILIHAT DARI SERVICE QUALITY, FOOD QUALITY DAN PRICE/VALUE DI RESTORAN MCDONALD'S DEPOK
}

\author{
Riri Mayliza \\ Sekolah Tinggi Ilmu Ekonomi "KBP” Padang \\ ririmayliza@akbpstie.ac.id
}

\begin{abstract}
Increasing public economic development has in turn made increasing public activities. Thus, in the highly competitive service industries such as fast food restaurants, it is very essential to satisfied customer. This may be achieved through the high quality of the service, food, and price the service provided by producer. The objective of this research was : (a) the positive effect of service quality on customer satisfaction, (b) the positive effect of food quality on customer satisfaction, (c) the positive effect of price/value on customer satisfaction, $(d)$ the positive effect of customer satisfaction on behavioural intention. The design of this research applies a survey on McDonald's restaurant as the unit of analysis by interviewing in the customers to test the hypothesis. The data consist of five variables including service quality, food quality, and price/value attribute as independent variables, customer satisfaction as intervening variable and behavioural intention as dependent variable. A number of 177 customers were selected as the respondents this research Data analysis used in this research consists of Structural Equation Method by LISREL software. The results of this research concluded that variables of service quality, food quality, and price/value had positive effects on customer satisfaction, and variable of customer satisfaction had positive effect on behavioural intention.
\end{abstract}

Keywords: service quality, food quality, price, value, customer satisfaction dan behavioral intention

\section{PENDAHULUAN}

Perkembangan ekonomi masyarakat yang pesat membuat kesibukan masyarakat juga semakin meningkat. Lebih lanjut maka akibatnya, banyak anggota msyarakat yang merasakan bahwa waktu sangat berharga bagi mereka sehingga timbul kesadaran berlebihan terhadap waktu kerja dibanding kegiatan lain seperti memasak. Pada akhirnya waktu untuk menyediakan makanan dan minuman di rumah semakin sempit, yang pada gilirannya yang membuat mereka lebih memilih membeli makanan dan minuman di luar rumah, yaitu di restoran. 
Pada dasarnya restoran adalah suatu tempat atau bangunan yang diorganisasikan secara komersil, yang menyediakan pelayanan yang baik terhadap semua tamunya baik berupa makanan maupun minuman (Marsum, 2005). Dalam hal ini tujuan operasi restoran selain untuk mencari untung, juga untuk membuat puas para tamu. Untuk itu pelayanan menjadi faktor penting agar kelangsungan usaha restoran tetap berlanjut.

Marsum (2005) menyebutkan bermacam-macam tipe restoran salah satunya adalah restoran cepat saji /RSC atau dalam bahasa inggrisnya (Fast Food Restaurant/FFR). Pada restoran cepat saji, hampir dipastikan layanannya bersifat selfservice. Biasanya tamu berdiri di depan antre untuk memesan makanan dan minuman. Setelah itu kemudian langsung bayar dan mengambil tisue, sedotan, sambal, dan sebagainya sendiri-sendiri. Keramahtamahan dalam sistem pelayanan ini relatif kurang.

Pada hakikatnya, Service quality yang diinginkan menjadi faktor penentu bagi keberhasilan organisasi karena hubungannya yang langsung dengan customer satisfaction dan behavioral intention (Parasuraman et al., 1985). Organisasi yang memberikan pelayanan superior juga mengalami customer satisfaction tingkat tinggi dan penilaian sangat baik dari mulut ke mulut (Gilbert et al., 2004; Gilbert dan Veloutsou, 2006). Persepsi pelanggan terhadap service quality penting bagi organisasi internasional karena ukuran-ukuran seperti itu rentan terhadap faktorfaktor dan keragaman budaya (Firrer et al., 2000; Heskett et al., 1990; Mattila, 1999; Trompenaars, 1994). Para pelanggan di negara-negara yang berbeda dapat memiliki persepsi yang berbeda tentang service quality karena sebagian disebabkan oleh perbedaan-perbedaan budaya dan lingkungan.

Selanjutnya pada hakikatnya penelitian ini akan mengisi kesenjangan unik dalam literatur service quality dengan meneliti isu-isu yang telah disebutkan di atas. Pertama, akan dicoba mengembangkan model keberhasilan FFR untuk Indonesia dengan meneliti determinan kunci dari service quality dan customer satisfaction. Setelah berhasil menyusun ukuran-ukuran keandalan dan keabsahan yang memadai, Kemudian dilanjutkan dengan tujuan lain - untuk meneliti hubungan teoritis antara service quality, food quality, price/value, customer satisfaction, dan behavioral intention dalam industri makanan cepat saji di Indonesia.

\section{Perumusan Masalah}

Dari uraian latar belakang maka dapat dinyatakan perumuran masalahnya sebagai berikut: (1) Apakah terdapat pengaruh Customer Satisfaction (CS) terhadap Behavioral Intention (BI)?, (2) Apakah terdapat pengaruh Service Quality (SQ) terhadap Customer Satisfaction (CS)?, (3) Apakah terdapat pengaruh Food Quality (FQ) terhadap Customer Satisfaction (CS)?, (4) Apakah terdapat pengaruh hubungan Price/Value (PV) terhadap Customer Satisfaction (CS)?

\section{TINJAUAN PUSTAKA}

\section{Service Quality}

Parasuraman et al. yang dikutip Lien-Ti Bei dan Yu Ching Chao (2001) telah membentuk sebuah model penelitian, yang dikenal dengan the Five-Gap, dan telah menghasilkan struktur dan pengukuran mengenai service quality. Mereka berpendapat bahwa metode-metode yang digunakan untuk mengukur service 
quality dan customer satisfaction pada dasarnya sama, yang dalam hal ini keduanya dihasilkan berdasarkan pada perbandingan mengenai harapan dan yang benar-benar diharapkan oleh konsumen. Oliver (1993) menyatakan, bahwa beberapa kontak jasa bagi para. konsumen sangat penting untuk memutuskan apakah mereka memang benar-benar puas, tetapi untuk service quality, pengakuan mengenai service quality ini dapat dilakukan dengan atau tanpa penggunaan jasa yang sebenarnya.

Menurut Parasuraman et al dalam Lien-Ti Bei dan Yu Ching Chao (2001), sebagian besar peneliti menyatakan, bahwa service quality yang tinggi dapat menghasilkan customer satisfaction yang tinggi. Bitner dalam Lien-Ti Bei dan Yu Ching Chao (2001) menyatakan bahwa, service quality yang baik akan menghasilkau kepuasan dan customer satisfaction akan meningkatkan mutu dari suatu pelayanan. Beberapa penelitian mendukung penyataan, bahwa service quality akan berpengaruh terhadap kepuasan, dan selanjutnya akan mempengaruhi perceived service quality secara signifikan. Teas (1993) juga menyebutkan, bahwa perceived service quality adalah hasil akumulasi dari customer satisfaction. Kotler (2000) mengungkapkan, bahwa suatu produk jasa merupakan produk yang memiliki karakteristik tidak berwujud (intangibility), tidak terpisahkan (inseparibility), bervariasi (variability) dan mudah lenyap (perishability).

Kualitas menurut Montgomery (1997), adalah "Quality is the extent to which products meet the requirements of people who use them". Sementara itu service quality menurut Parasuraman, Zeithaml dan Berry (1990) adalah: "Good service quality is meeting or exceeding what customers expect from the service. Judgments of high and iow service quality depend on how customers perceive the actual service performance in the coniex of what they expected".

\section{Food Quality}

Pada dasarnya Food Quality dapat diartikan sebagai kualitas makanan dan minuman yang dihidangkan kepada para tamu (konsumen). Menurut Sugiarto (1999). Salah satu kunci untuk mensukseskan bisnis restoran, dalam hal ini juga restoran cepat saji adalah kualitas makanan khususnya rasa hidangan berupa makanan dan minuman yang enak. Selanjutnya dikatakan pula ada beberapa hal yang berkaitan dengan kualitas makanan, yaitu pembelanjaan bahan baik yakni bahan mentah yang baik, pengelolaan yang tepat dengan menggunakan standar menu yang ada, serta cara menghidangkan makanan yang pas yaitu baik penampilannya.

Marsum (2005), menyebutkan beberapa aspek yang berkaitan dengan food quality yaitu : (1) Flavour (rasa/bau), (2) Consistency (kemantapan/ketetapan), dan (3) Texture/Form/Shape (susunan/bentuk/potongan).

\section{Price/Value}

Berhubungan dengan harga dan kepuasan. Zeithaml dan Bitner (1996) menyatakan bahwa tingkat kepuasan, jauh lebih luas dibandingkan dengan penilaian service quality dan merupakan subyek dari berbagai faktor di dalam kualitas pelayanan, kualitas produk, harga, situasi, dan faktor-faktor pribadi. Anderson, Fornell dan Lehmann (1994) juga menekankan harga sebagai sebuah faktor yang sangat penting dari kepuasan konsumen karena kapanpun konsumen mengevaluasikan nilai dari jasa yang diperoleh dan mereka biasanya memikirkan 
mengenai harga. Sedangkan definisi harga menurut Zeithmal dalam Voss, Glenn, Parasuraman, dan Grewal (1998) adalah sebagai berikut: "price is translation [of the objectice price] into cognitions that are meaningful and relevant to the customer". Dalam hal ini, harga dibagi menjadi tiga kategori, yaitu : reasonable price (harga yang ditetapkan rasional/masuk akal), expensive price (harga yang ditetapkan relatif mahal), dan pleased -with price (harga yang ditetapkan sesuai dengan yang ditawarkan). Zeithaml dan Bitner (1996) percaya, bahwa alasan mengapa variabel harga (price) tidak dibahas secara tepat di dalam pengukuran mengenai service quality adalah karena kurangnya referensi dari konsumen mengenai harga.

\section{Customer Satisfaction}

Dijelaskan bahwa customer satisfaction sebagai sebuah keadaan psikologis untuk menilai pemahaman antara apa yang benar-benar diharapkan dan diberikan pada seorang konsumen (Howard dan Sheth dalam Li-Tien Bei dan Yu Ching Chao, 2001). Churchill $d k k$ dalam Li-Tien Bei dan Yu Ching Chao (2001) menyatakan bahwa customer satisfaction dihasilkan dari pembelian dan penggunaaan produk tertentu, dimana konsumen membandingkan penghargaan yang diharapkan dan biaya pembelian yang sebenarnya. Dalam sebuah penelitian mengenai barang tahan lama, faktor utama dari customer satisfaction bukan perbedaan antara kinerja produk dan harapan terhadap produk. Faktor yang paling menentukan dalam customer satisfaction adalah "production performance". Parasuraman, Zeithaml dan Berry (1994) menyatakan bahwa service quality, product quality dan price, secara bersama-sama akan mempengaruhi kepuasan. Voss dkk. (1998) menyatakan bahwa kepuasan akan dihasilkan dari fungsi harga, harapan dan kinerja.

Dua defenisi kepuasan pelanggan menurut Kotler (2000) yaitu: The extend to which product' perceived performance matches a buyer's expectation. If the product performance fall short of expectation, the buyer is dissatisfied. If performance matches or exceed expectation, the buyer is satisfied or delighted. Sedangkan Gundersen $d k k$ (1996) berdasar atas studi yang telah dilakukan mendefmisikan kepuasan sebagai berikut: "Customer satisfaction is a post consumption evaluate judgement concerninga specific product or services". Menurut Kindaris (2004) kepuasan merupakan kondisi akhir yang diinginkan individu dalam mengkonsumsi suatu produk atau jasa, dengan meniadakan kebutuhan untuk mengambil suatu tindakan akhir yang diinginkan individu dalam mengkonsumsi produk atau jasa. Zeithaml dan Bitner (1996) mengemukakan bahwa, kepuasan adalah konsep yang jauh lebih luas dari hanya sekedar penilaian kualitas pelayanan, tetapi juga dipengaruhi oleh faktor-faktor lain.

\section{Behavioral Intention}

Behavioral Intention merupakan hasil dari proses kepuasan (Anderson et al, 1994;. Anderson dan Mittal, 2000). Behavioral Intention dapat dikelompokkan menjadi dua kategori, Economic Behavioral Intention dan Social Behavioral Intention (Smith et al, 1999.). Economic Behavioral Intention adalah perilaku pelanggan yang mempengaruhi aspek keuangan perusahaan seperti perilaku pembelian berulang (Anderson dan Mittal, 2000), kesediaan membayar lebih, dan beralih perilaku (Zeithaml et al, 1996). Meningkatkan kepuasan secara 
keseluruhan mengarah ke tujuan pembelian kembali lebih besar (Anderson et al, 1994;. Anderson dan Mittal, 2000; Ralston, 1996; Zeithaml et al, 1996), serta perilaku pembelian kembali yang aktual (Anderson dan Mittal, 2000;. Bolton, 1998). Social Behavioral intention adalah perilaku pelanggan yang mempengaruhi tanggapan dari pelanggan yang ada dan potensi lain dari perusahaan seperti perilaku keluhan (Johnston, 1998; Nyer, 1999; Pajak et al, 1998.) dan komunikasi melalui word of mouth (Szymanski dan Henard, 2001; Wright et al, 1996.). Social Behavioral Intention, baik positif maupun negatif, dampak individu pelanggan serta untuk mempengaruhi pendapat pelanggan lain. Informasi disebarluaskan dari mulut ke mulut dari pelanggan yang ada ini kemudian digunakan sebagai masukan bagi harapan pelanggan masa depan (Anderson et al, 1994.). Konsumen mengambil hasil kinerja suatu produk/layanan dan kemudian menggunakan informasi tersebut untuk membentuk ekspektasi mereka sendiri berikutnya serta harapan orang lain melalui word of mouth (Oliver, 1997).

Menurut model yang dihasilkan oleh Zeithaml, Berry, dan Parasuraman (1996), Behavioral intention dapat ditangkap oleh langkah-langkah seperti niat pembelian kembali, dari mulut ke mulut, loyalitas, mengeluh perilaku, dan sensitivitas harga. Zeithaml, Bitner, dan Parasuraman (1996) lebih menekankan bahwa Behavioral Intention dapat dilihat ketika seorang pelanggan memutuskan untuk tetap membeli dengan atau cacat dari perusahaan. Burton et al. (2003), menyimpulkan bahwa pengalaman pelanggan berkaitan dengan Behavioral Intention.

\section{Customer Loyality}

Customer satisfaction menghasilkan kesetiaan (loyalitas) terhadap merek (Cronin dkk. 2000, 1992, Lee, 1998, McDougall and Levesque, 2000). Di dalam sebuah odifikasi terhadap penjelsan Oliver (1997), disebutkan bahwa kesetiaan (loyalty) dijelaskan sebagai komitmen yang dihasilkan untuk melakukan pembelian atas produk dan jasa yang diingikan secara konsisten dimasa yang akan datang.

Jacoby dan Chestnut dalam Li-Tien Bei dan Yu Ching Chao (2001) menyimpulkan bahwa pembelian yang dilakukan secara konsisten adalah sebuah indikator dari kesetiaan yang dapat juga menjadi sebuah hal yang tidak valid di dalam perilaku pembelian atau sebuah pilihan untuk melakukan pembelian yang tidak konsisten terhadap beberapa merek di dalam kategori sebuah produk. Oleh karena itulah, beberapa peneliti lebih menekankan penelitian terhadap customer loyalty dan penjelasan dari customer loyalty berdasarkan pada perilaku dan sikap (Oliver, 1997). Banyak juga penelitian empiris yang telah dilakukan (Cronin $d k k$. 2000, 1992; Lee, 1998; McDougall and Levesque, 2000) menyatakan bahwa konsumen yang puas akan menunjukkan perilaku yang lebih setia.

\section{Kerangka Konseptual}

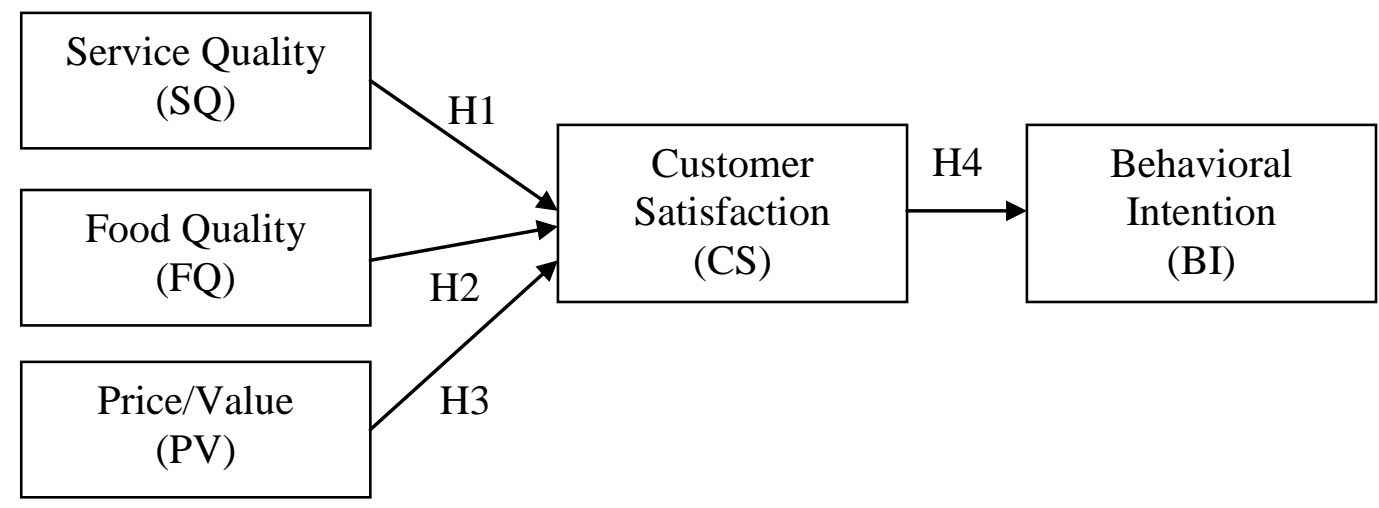




\section{Perumusan Hipotesa}

Sebuah telaah literatur/pustaka mengungkapkan studi-studi sebelumnya yang melaporkan hubungan positif antara Service Quality dengan Customer Satisfaction (Cronin et al., 2000; Wong dan Sohal, 2006; Cai, 2009). Namun demikian, pertanyaan orde service quality yang diinginkan dan kepuasan dalam pelayanan masih tetap belum terjawab dan menyebabkan debat dalam literatur pemasaran. Beberapa studi berdasarkan Indeks Customer satisfaction Eropa dan Indeks Customer satisfaction Amerika menunjukkan bahwa service quality merupakan salah satu dari pendugapenduga customer satisfaction. Rangkaian model berbasis penelitian lainnya bertentangan dengan tuntutan dan argumen bahwa service quality merupakan konsekuensi dari customer satisfaction. Gonzales et al. (2007) meneliti kedua hubungan tersebut dan menyimpulkan bahwa kepuasan bergantung pada service quality yang diinginkan. Sejalan dengan penelitian tersebut, kami mengusulkan bahwa:

H1. Customer Satisfaction berpengaruh langsung dan positif terhadap Behavioral

Intention bagi para konsumen Indonesia dalam industri makanan cepat saji.

Sebagai tambahan untuk service quality, juga dimasukkan harga dan kualitas produk yang mempengaruhi customer satisfaction (Andaleeb dan Conway, 2006; Parasuraman et al., 1994). Food quality sangat berkaitan dengan kepuasan dalam FFR (John dan Howard, 1998; Kivela et al., 1999; Law et al., 2004) dan diuji dalam studi ini sebagai determinan potnesial dari customer satisfaction. Akibatnya, hipotesis keempat adalah: H2. Food quality berpengaruh langsung dan positif terhadap Customer Satisfaction Indonesia.

Price/value juga mempengaruhi customer satisfaction karena kemampuannya untuk menarik atau menjauhkan para pelanggan (Monroe, 1989), dengan demikian price/value dipandang sebagai komponen customer satisfaction. Berdasarkan temuantemuan dari penelitian terdahulu (Fornell et al., 1996; Gilbert et el., 2004; Kara et al., 1995; Lee dan Ulgado, 1997), kami mengusulkan bahwa price/value adalah salah satu dari penduga-penduga customer satisfaction tetapi tidak berkaitan dengan pelayanan dan food quality. Oleh sebab itu, hipotesis berikutnya adalah:

H3. Price/value berpengaruh langsung dan positif terhadap Customer Satisfaction Penelitian oleh (Cronin et.al) menjelaskan adanya hubungan positif antara Customer Satisfaction dengan Behavioral Intention (Wong dan Sohal, 2006) juga menjelaskan adanya hubungan positif antara Customer Satisfaction dan Behavioral Intention, Customer Satisfaction mempunyai pengaruh positif dan signifikan terhadap Behavioral Intention (Cai,2009). Dari penjelasan diatas di dapat menunjukan bahwa hasil hipotesis adalah :

H4. Customer Satisfaction berpengaruh langsung terhadap Behavioral Intention

\section{Rancangan Penelitian}

Penelitian ini mengacu kepada penelitian yang dilakukan oleh Hong Qin (2010), merupakan survey untuk menguji hipotesis, yaitu suatu penelitian yang bertujuan untuk menjelaskan pengaruh Perceived Service Quality, Food Quality, dan Price/Value terhadap Customer Satisfaction dan Behavioral Intention. Dalam penelitian ini, akan diuji beberapa hipotesis yang muncul didalam pengaruh yang 
terjalin antara Service Quality, Food, dan Value terhadap Customer Satisfaction dan Behavioral Intention.

\section{Variabel dan Pengukuran}

Dalam penelitian ini terdapat beberapa variabel yang hendak diteliti. Data yang diperlukan terdiri dari dua variabel yaitu variabel independent (eksogen) Service Quality, Food Quality, Price/Value, sedangkan variabel dependent (endogen) Customer Satisfaction, dan Behavioral intention.

\section{Service quality}

Variabel Service Quality terdiri dari enam dimensi yaitu tangible, keandalan, jaminan, daya tanggap, empati, dan recoverability yang diambil dari (Hong Qin,

2010).

Untuk Tangible didapat dari Cronin dan Taylor (1992) Johns dan Howard (1998) Kara et al. (1995) dalam Hong et.al (2010)

1. Ruang makan yang bersih.

2. Pekerja yang berpakaian baik.

3. Menggunakan sarung tangan sekali pakai dan jaring rambut.

4. Ketersediaan tempat duduk.

5. Ketersediaan tempat

Keandalan didapat dari Cronin dan Taylor (1992) dalam Hong et.al (2010)

1. Memberikan pelayanan sebagaimana yang dijanjikan

2. Simpatik dan meyakinkan

3. Pelayanan tepat waktu yang dapat diandalkan yang akurat

Jaminan didapat dari Cronin dan Taylor (1992) dalam Hong et.al (2010)

1. Pekerja yang dapat dipercaya

2. Perasaan aman dalam transaksi keuangan

3. Pekerja yang berpengetahuan

Daya Tanggap didapat dari Cronin dan Taylor (1992) dalam Hong et.al (2010)

1. Mengatakan waktu pelayanan yang tepat

2. Pekerja selalu siap melayani permintaan

3. Pelayanan tepat waktu

4. Pekerja bersedia membantu

Empati Ditambahkan sesuai dengan diskusi dengan fakultas dan mahasiswa China

Cronin dan Taylor (1992), Johns dan Howard (1998) dalam Hong et.al (2010)

1. Ketersediaan makanan anak-anak

2. Ketersediaan hiburan anak-anak

3. Ketersediaan saos, dsb

4. Jam operasi yang nyaman

5. Lokasi yang nyaman

6. Makanan yang dikemas lengkap

Daya pemulihan didapat dari Olorunniwo et al. (2006)

1. Pekerja cepat meminta maaf atas kekeliruan

2. Perhatian terhadap keluhan pelanggan

3. Ketrampilan dan kemampuan untuk menangani keluhan

4. Pekerja diberdayakan untuk memberikan kompensasi

\section{Food quality}

Food quality didapat dari Johns dan Howard (1998) Kivela et al. (1999)

1. Segar

2. Penyajian 
3. Dimasak matang

4. Aneka ragam makanan dan minuman

\section{Price/value}

Price/value didapat dari Kim dan Kim (2004) Kara et al. (1995)

1. Harga makanan yang kompetitif

2. Harga minuman yang kompetitif

3. Nilai yang tinggi untuk harga produk

\section{Customer satisfaction}

Customer satisfaction di dapat dari Olorunniwo et al. (2006)

1. Puas dengan makanan

2. Pilihan makanan yang bijaksana

3. Hal yang tepat

4. Pengalaman yang menyenangkan

\section{Behavioral intention}

Behavioral intention diapat dari Boulding et al. (1993) Kellor et al. (2004)

1. Rekomendasi

2. Berniat untuk makan lagi di tempat tersebut

3. Mengatakan hal-hal baik tentang FFR

Metode penilaian diatas menggunakan skala likert 5-point yaitu :

$5 \quad$ : Sangat Setuju

$4 \quad$ : Setuju

3 : Biasa

2 : Tidak setuju

1 : Sangat tidak setuju

\section{Sampel dan Pengumpulan Data}

Metode penarikan sampel data adalah dengan menggunakan metode teknik convenience sampling dimana dengan menemui responden yang dijumpai dengan menyebarkan kuesioner kepada pengunjung restoran McDonald's di wilayah Depok dalam jangka waktu satu bulan terakhir dengan jumlah responden 170 responden.

\section{Karakteristik Demografi Responden}

Data yang diperoleh melalui kuesioner, bahwa mayoritas responden konsumen (57.63 $\%$ dari total responden konsumen) yang didapat dari penelitian ini adalah wanita, berdasarkan usia mayoritas responden adalah berusia sekitar 15-19 tahun yaitu sebesar $25,42 \%$, berdasarkan tingkat pendidikan yang lebih mendominasi adalah yang berpendidikan S1 yaitu sebesar 32,20\%, berdasarkan jenis pekerjaan yang paling dominasi adalah pelajar dengan 23,16 \% dan apabila dilihat berdasarkan pendapatan per bulan mayoritas antara Rp. 1.000.000,- - Rp. 2.500.000.- sebesar 50,28\%. Sedangkan dilihat dari jumlah frekuensi kunjungan mayoritas berkunjung lebih dari 3 kali dalam 1 bulan yakni dengan 42,94\%.

\section{Hasil Pengujian Hipotesis}

\begin{tabular}{lllll}
\hline & Hipotesis & $\begin{array}{l}\text { Koefisien } \\
\text { Parameter }\end{array}$ & t value & t Tab \\
\hline H 1 & Service Quality-Customer Satisfaction & 0,18 & 2,4 & 1,96 \\
H 2 & Food Quality-Customer Satisfaction & 0,35 & 4,32 & 1,96 \\
H 3 & Price/Value-Customer Satisfaction & 0,44 & 5,19 & 1,96 \\
H 4 & Customer Satisfaction-Behavioral Intention & 0,91 & 10,5 & 1,96 \\
\hline
\end{tabular}




\section{Pembahasan Hasil Penelitian}

Berdasarkan hasil pengujian hipotesa pada Tabel diatas, dari keempat hipotesa yang digunakan, variabel service quality, food quality, dan price/value mempunyai pengaruh terhadap customer satisfaction sedangkan variable customer satisfaction mempunyai pengaruh terhadap behavioral intention. Adapun pembahasan keempat hipotesa yang digunakan adalah sebagai berikut :

\section{Hipotesa 1}

Berpengaruhnya service quality terhadap customer satisfaction menunjukkan bahwa restoran McDonald's berupaya agar service quality yang telah terbentuk dapat dijalankan dengan benar. Hal ini menjadi prioritas utama perusahaan dalam memuaskan para pelanggannya. Dengan menjaga service quality tersebut perusahaan akan terus menjaga apa yang sudah diberikan kepada para pelangganya sehingga berusaha untuk memenuhinya kepuasan para pelanggan.

Penelitian sebelumnya yang melaporkan hubungan positif antara Service Quality dengan Customer Satisfaction (Cronin et al., 2000; Wong dan Sohal, 2006; Cai, 2009). Namun demikian, pertanyaan orde service quality yang diinginkan dan kepuasan dalam pelayanan masih tetap belum terjawab dan menyebabkan debat dalam literatur pemasaran. Beberapa studi berdasarkan Indeks Customer satisfaction Eropa dan Indeks Customer satisfaction Amerika menunjukkan bahwa service quality merupakan salah satu dari penduga-penduga customer satisfaction. Rangkaian model berbasis penelitian lainnya bertentangan dengan tuntutan dan argumen bahwa service quality merupakan konsekuensi dari customer satisfaction. Gonzales et al. (2007) meneliti kedua hubungan tersebut dan menyimpulkan bahwa kepuasan bergantung pada service quality yang diinginkan

\section{Hipotesa 2}

Berpengaruhnya food quality terhadap customer satisfaction menunjukkan bahwa restoran menjaga kualitas makanan yang disajikan sesuai dengan prosedur yang ada di McDonald's. McDonald's sangat menjaga kualitas makanannya mulai dari bahan mentah hingga menjadi makanan yang siap disantap oleh pelanggan. Dengan menjaga kualitas makanan maka restoran berusaha untuk memenuhi kepuasan para pelanggannya.

Penelitian sebelumnya, sebagai tambahan untuk service quality, juga dimasukkan harga dan kualitas produk yang mempengaruhi customer satisfaction (Andaleeb dan Conway, 2006; Parasuraman et al., 1994). Food quality sangat berkaitan dengan kepuasan dalam FFR (John dan Howard, 1998; Kivela et al., 1999; Law et al., 2004) dan diuji dalam studi ini sebagai determinan potnesial dari customer satisfaction.

\section{Hipotesa 3}

Berpengaruhnya price/value terhadap customer satisfaction menunjukkan bahwa restoran McDonald's mempunyai harga makanan ataupun minuman yang sangat kompetitif. Nilai dari suatu produk McDonald's juga sangat baik sehingga menjadikan pelanggan puas akan harga ataupun nilai dari produk McDonald's.

Price/value juga mempengaruhi customer satisfaction karena kemampuannya untuk menarik atau menjauhkan para pelanggan (Monroe, 1989), dengan demikian price/value dipandang sebagai komponen customer satisfaction. Berdasarkan temuantemuan dari penelitian terdahulu (Fornell et al., 1996; Gilbert et el., 2004; Kara et al., 1995; Lee dan Ulgado, 1997), 


\section{Hipotesa 4}

Berpengaruhnya customer satisfaction terhadap behavioral intention menunjukkan bahwa pelanggan McDonald's akan berperilaku yang baik ketika dia puas. Akan tetapi sebaliknya, jika pelanggan McDonald's merasa tidak puas maka dia akan berperilaku yang negative tentang McDonald's. Disini ada keterkaitan antara customer satisfaction dengan behavioral intention.

Penelitian oleh (Cronin et.al) menjelaskan adanya hubungan positif antara Customer Satisfaction dengan Behavioral Intention (Wong dan Sohal, 2006) juga menjelaskan adanya hubungan positif antara Customer Satisfaction dan Behavioral Intention. Customer Satisfaction mempunyai pengaruh positif dan signifikan terhadap Behavioral Intention (Cai,2009).

\section{KESIMPULAN}

Hasil temuan dari penelitian ini pada industri jasa restoran McDonlad's dengan jelas memperlihatkan hasil untuk hipotesis $\mathrm{H} 1$ bahwa service quality mempunyai pengaruh yang signifikan terhadap customer satisfaction. Kondisi ini didukung dengan hubungan positif dan signifikan dari keseluruhan dimensi service quality terhadap customer satisfaction. Sedangkan untuk hipótesis $\mathrm{H} 2$ bahwa food quality mempunyai pengaruh terhadap customer satisfaction. Kondisi ini didukung dengan hubungan positif dan signifikan dari keseluruhan dimensi food quality terhadap customer satisfaction. Kemudian hipótesis H3 bahwa Price/value mempunyai pengaruh terhadap customer satisfaction. Kondisi ini didukung dengan hubungan positif dan signifikan dari keseluruhan dimensi Price/value terhadap customer satisfaction. Selanjutnya untuk hipótesis $\mathrm{H} 4$ bahwa customer satisfaction mempunyai pengaruhnya terhadap behavioral intention. Kondisi ini didukung dengan hubungan positif dan signifikan dari keseluruhan dimensi customer satisfaction terhadap behavioral intention.

\section{Implikasi Manajerial}

Berdasarkan uji empiris hipotesis mengenai service quality terhadap customer satisfaction dan behavioral intention pada industri jasa restoran, beberapa temuan merupakan masukan berguna terutama diantaranya sebagai berikut:

1. Service quality, food quality maupun price/value harus tetap dipertahankan. Menurut masukan pelanggan bahwa McDonald's telah menjaga ketiga dimensi tersebut tetapi ada beberapa hal yang kurang dalam service quality. Kebersihan dan kenyamanan restoran masih kurang dijaga sehingga pelanggan tidak merasakan seperti berada di restoran terkenal. Hal ini juga terlihat dalam hal ketersediaan kursi dan meja yang masih agak kurang. Hendaknya hal tersebut harus dicermati dan dilakukan perbaikan sesegera mungkin.

2. Variabel customer satisfaction dengan behavioral intention mempunyai pengaruh positif yang signifikan. Semakin tinggi kepuasan pelanggan maka behavioral intention akan semakin baik. Begitu juga sebaliknya, semakin rendah kepuasan pelanggan maka behavioral intention akan semakin buruk. Untuk itu perlu diperbaiki temuan diatas yang terkait dengan pengaruh customer satisfaction terhadap behavioral intention.

3. Untuk lebih meningkatkan pemahaman kita ada baiknya pengaruh service quality, food quality, dan price/value terhadap customer satisfaction dan behavioral intention, perlu pengujian lagi pada perusahaan berbeda untuk melihat apakah 
terdapat konsistensi atas hasil penelitian-penelitian selanjutnya, dengan mempertimbangkan pengaruh variable lainnya.

\section{DAFTAR PUSTAKA}

Anderson, EW Fornel C And Lehman D.R (1994) "Customer Satisfaction, Market Share And Profitabality “ Journal Of Marketing, Vol 58 No 3

Anderson, EW And Mital, V (2000) "Strong Theing The Satisfaction Of The Customer-Profit Chain" Jurnal Of Service Research, Vol 3 No 2.

Aziz, N. (2019). Pengaruh Kualitas Layanan Terhadap Kepuasan Nasabah SMS Banking Pada Bank Nagari Cabang Pembantu RSUP DR M Djamil Padang. https://doi.org/10.17605/OSF.IO/S3JVG

Bulton, R.N (1998), "A dinamyc Model Of The Duration Of The Customer's Relationship With A Continuos Service Provider The Role Of Satisfaction" Marketing Sciene, Vol 17 No 1

Burton S, Sheafter S, And Robert, J (2003) "The Effect Of Actual And Perceived Performance On Saticfaction And Behavioral Intention " Journal Of Service Research, Vol 5 No 4

Cronin, J. Joseph, Jr., Michael K. Brady And G. Thomas M. Hult (2000), Assesing The Effects Of Quality, Value, And Consumer Satisfaction On Customer Behavioral Intentions In Service Environments, Journal Of Retailing, 76 (2), 193-218

Cronin, J.J. And Taylor, S.A. (1992), "Measuring Service Quality: A Re-Examination And Extension", Journal Of Marketing, Vol. 56. July, Pp.56-68.

Fernandes, Y. D., \& Marlius, D. (2018). Peranan Customer Service Dalam Meningkatkan Pelayanan Kepada Nasabah Pada PT. Bank Pembangunan Daerah Sumatera Barat Cabang Utama Padang. https://doi.org/10.31227/osf.io/wrh3p

Gronroos, C. (1984), "A Service Quality Model And Its Market Implications". European Journal Of Marketing, Vol. 18 No. 4. Pp. 36-44.

Hair J, Anderson EW, And Mittal, V (2000) "Strong poin The Satisfaction, Market Share And Profitability" Journal Of Market, Vol 58 No 3.

Hermawan, A (2003) Pedoman Praktis Metodelogi Bisnis Cetakan I LPFE. Universitas Trisakti. Jakarta

Jasfar F (2005). Manajemen Jasa: Pendekatan Terpadu Cetakan I Ghalia Indonesi. Bogor

Kotler, Philip (2000), Marketing Management, Prentice Hall, New York 
Lee M And Ulgado, FM (1998) Customer Evulation Of Fast Food Services : A CroosNation Comparison “Jurnal Of Service Marketing” Vol 11 No 1

Lien-Ti Bei And Yu Ching Chao (2001), An Integrated Model For The Effects Of Perceived Product, Perceived Service Quality, And Perceived Price Fairness On, Journal Of Consumer Research.

Marlius, D. (2018). Loyalitas Nasabah Bank Nagari Syariah Cabang Bukittinggi Dilihat Dari Kualitas Pelayanan. Jurnal Pundi. Volume 1. No. 3. Hal.12-22. https://doi.org/10.31575/jp.v1i3.60

Marlius, D. (2018). Pengaruh Dimensi Kualitas Pelayanan Website Akademik Terhadap Kepuasan Mahasiswa Pada STIE “KBP”. Jurnal Ipteks Terapan. Volume 12. No. 2. Hal. 116-128. http://doi.org/10.22216/jit.2018.v12i2.633

Marsum W.A. (2005) Restoran Dan Segala Permasalahan. Andi Yogyakarta

Oliver, Richard L. (1993), Cognitive, Affective, And Attribute Bases Of The Satisfaction Response, Journal Of Consumer Research, 20 (3), 418-430.

Oliver, Richard L. (1997), Satisfaction: A Behavioural Perspective On Consumers, New York .Mcgraw Hill, Maidenhead.

Pasuraman, A. Zeithmal, V. and Berry, L. (1985), "A Conceptual Model Of Service Quality And It's Implication For Future Research” Jurnal Of Marketing, Vol 49 No 4

Parasuraman, A., Zeithaml, V.A, \& Berry, L. (1994), Reassessment Of Expectations As A Comparison Standard In Measuring Service Quality: Implications For Further Research. Journal Of Marketing, 58 (January), 111-124.

Qin Hong. Victor R Pributok, Qilan Zhao (2010) "Perceived Service Quality In Fast Food Restaurant Emprical Evidence China, International Journal Of Quality \&Releabilty Management" Vol 27 No 4.

Ralston, R (1996), “Model Maps Out Sure Path To Growth in Market News” Journal of Marketing, Vol 30 No 11.

Rajesh Sethi. (2000). New Product Quality And Product Development Teams, Journal Of Marketing, 4, 1-14.

Reichheld, F. And Sasser, W., (1990) Zero Defections: Quality Comes To Services. Harvard Business Review, 68. (105-111).

Safitri, R. N., \& Marlius, D. (2017). Penerapan E-Banking Dalam Meningkatkan Jasa Dan Layanan Perbankan Di PT. Bank Rakyat Indonesia Cabang Padang. https://doi.org/10.31227/osf.io/gkv8t 
Smith, A.K Bulton R.N And Wagner, J (1999) “A Model Of Customer Satisfaction Whitch Service And Customer Inolving Kailure And Recovery, " Journal Of Marketing, Research, Vol 36 No 3

Sugiarto, Endar (1999) Psikologi Pelayanan Dalam Industri Jasa. Gramedia Jakarta

Susanti, F. W Ekazaputri. (2018). Service Performance Dan Kepuasan Sebagai Moderating Variabel Terhadap Loyalitas Nasabah Pada PT BPR Labuh Gunung Payakumbuh Jurnal Benefita: Ekonomi Pembangunan Manajemen Bisnis Dan Akuntansi. Volume 3. No. 3. Hal. 433444.http://doi.org/10.22216/jbe.v3i3.3472

Teas, R. Kenneth (1993), Expectations, Performance Evaluation And Customer's Perceptions Of Quality. Journal Of Marketing, 57 (October), 18-34.

Tiza, M. F., \& Susanti, F. (2019). Pengaruh Kualitas Pelayanan Terhadap Kepuasan Pelanggan, Studi kasus pada perusahaan JNE Cabang Padang. https://doi.org/10.31227/osf.io/hx87m

Ulfa, M., \& Mayliza, R. (2019). Pengaruh Kualitas Pelayanan Dan Kepuasan Pelanggan Terhadap Loyalitas Pelanggan PDAM Kota Padang. https://doi.org/10.31219/osf.io/spmgv

Voss, Glenn B., A. Parasuraman And Dhruvgrewal (1998), The Role Of Price, Performance, And Expectations In Determining Satisfaction In Service Exchanges, Journal Of Marketing. 62 (October), 46-61.

Zeithaml, Valerie A. And Bitner, Mary Jo (1996), Services Marketing. Mcgraw-Hill International Editions.

Zeithaml, Valerie; Berry, Leonard L.; And Parasuraman, A. (1996). The Behavioral Consequences Of Service Quality. Journal Of Marketing, 60. (31-46). 